\title{
Living in the Corpse. Functions of Tuberculosis and Forms of Its Representation in Croatian Literature and Culture in the Late $19^{\text {th }}$ and Early $20^{\text {th }}$ Century
}

\begin{abstract}
Vuković Tvrtko, Living in the Corpse. Functions of Tuberculosis and Forms of Its Representation in Croatian Literature and Culture in the Late $19^{\text {th }}$ and Early $20^{\text {th }}$ Century. "Poznańskie Studia Slawistyczne" 13. Poznań 2017. Publishing House of the Poznań Society for the Advancement of the Arts and Sciences, pp. 95-108. ISSN 2084-3011.

In the second half of the $19^{\text {th }}$ century, social development based on science, technological innovation, rationalism and capitalist economy presents itself as full of promise insofar as it proclaims the upcoming progress of civilization. The downside of this process is the increase in crime, massive neurosis, various forms of moral disorder, and the epidemics of somatic diseases such as tuberculosis and syphilis. Consequently, the perception of the new generation as degenerate is actually the way to articulate anxiety in the culture of the time. Croatian literature at the end of the $19^{\text {th }}$ and at the beginning of the $20^{\text {th }}$ century frequently refers to illness, bodies burdened by drives, and to sick, tense or perverted minds. The paper, therefore, reads tuberculosis as a metaphor for the discontent and fear that permeate the contemporary Croatian society due to, for instance, the failure of the traditional concept of identity, changed gender roles, frequent sexual transgressions, increased mortality and generally due to the inefficiency of modernization processes in solving numerous social problems and crises.
\end{abstract}

KeYwords: modernism; tuberculosis; degeneration; civil society; fin-de-siècle Croatian literature

From its first issue in 1877 until the end of World War I in 1918, "Liječnički vjesnik" ("Medical Journal") published around 70 reports and articles on tuberculosis. At the turn of the $19^{\text {th }}$ century, tuberculosis was a burning healthcare issue that ultimately formed a variety of cultural fantasies related to the fear of societal collapse, the feeling of uneasiness with the unknown and the disturbing aspects of progress, and the dread of severe healthcare and social deprivation of future generations. The extent of this 
anxiety is noticeable in an article from 1899 entitled "Measures against the Spreading of Tuberculosis Arising from the Consumption of Meat and Milk of Tuberculosis-ridden Cows" (Sredstva proti širenju tuberkuloze nastale užitkom mesa i mlieka od tuberkuloznih krava), by royal county governor, Dr Josip Hoholač. Hoholač noted that tuberculosis had been rapidly

spreading across Europe, particularly in our Austro-Hungarian Empire. Statistical data proves this phenomenon and shows that the death rate is much higher than with other diseases. - It was Weichselbaum who indicated in his lecture in 1896 that the tuberculosis death rate in Austria-Hungary had been 10-14\%. However, this percentage is twice as high, as pathological anatomists know best. (...) A patient transmits the tuberculosis bacillus by coughing or using objects, but it is also transmitted through food; in that case, the domestic animal spreads the disease, not a human. As Koch's research has shown, tuberculosis can spread from animals to humans since it has been proved that the bacillus causing tuberculosis in animals is identical to the bacillus causing the disease in humans (Hoholač, 1899, 188).

An article by Dr Milivoj Dežman, assistant physician at the Hospital of Brothers of Mercy (Bolnica Milosrdne braće) in Zagreb, from 1904 attests to the extent to which tuberculosis caused contradictions and mystifications, even in medical circles. He openly warned of the "enormous bacteriological haze" that hung over the etiological, diagnostic, therapeutic, and prophylactic issues “after Koch's discovery in 1882" (Dežman, 1904, 284).

It was not definitely proven as to why and how the tuberculosis bacillus infects a human. Since the etiology was not entirely clear - considering that the pathway of the infection was not known - therapy was based on empirical methods, not scientific grounds, which led to the fact that doctors promoted all kinds of treatment, even the most absurd ones (Dežman, 1904, 285).

Despite the advancement of medicine and the discovery of the cause of the disease, tuberculosis remained "by definition, mysterious" (Sontag, $1978,5)$. Even after the etiology became more or less clear and the treatment almost entirely successful, still "TB was thought to be an insidious, implacable theft of a life" (Sontag, 1978, 5). Sontag emphasizes that numerous uncertainties that surrounded the disease for centuries continued to incite dread and moral panic in the cultural imagery of fin de siècle.

This is linked to the fact that Croatian civil society saw an increasing interest in the idea of degeneration. Due to a rise in contradictory, confounding, 
and menacing social occurrences and processes that bureaucratic, technological, and scientific mechanisms could no longer justify or control, the medical, legal, scientific, political, entrepreneurial, and cultural establishment of the time developed a feeling of deep discomfort. Degeneration enabled the transfer of this feeling to the discourse of empirical science. Where a deviation, a pathology or a subversion occurred from the perspective of the elites and the civil community, degeneration theory would step in to differentiate between the healthy and unhealthy, the normal and abnormal or the advanced and primitive. ${ }^{1}$ In that sense, tuberculosis "functioned as [a site] of social anxiety" (Byrne, 2013, 1). It was a form of abnormality that degeneration theory attempted to explain in order to prevent its adverse effects through established mechanism of social hygiene. ${ }^{2}$

Since "degeneration is discursively activated to produce (...) typologies of «inclusion» and «exclusion»" (Greenslade, 2010, 3), and tuberculosis was one of the immediate signs of degenerative social processes and a trigger for that kind of strategic selection of bodies, its symbolic potential was quite powerful at the time. As its "origins were shrouded in mystery" (Byrne, 2013, 2) and since it was unknown why only some and not all exposed to Koch's bacillus fell ill, the TB metaphor managed to embody cultural fears spawned by various aspects of abnormality, ranging from gender transgressions, sexual deviations, identity contradictions to anarchism, crime, and civil disobedience. In that sense, the capacity of

${ }^{1}$ Cf. Vuković, 2016.

${ }^{2}$ One of our first experts in degenerative diseases... and advocates of eugenics was Bogomil Kohout. His work is an indication of the technology of dealing with the abnormal. Kohout's eugenics functions as the shield against irreparably dangerous people who can take society hostage. With the help of the methodology of pathological heredity, it became a discipline of the scientific protection of society. Here is an illustrative paragraph: "History has well shown that marriages of the mentally ill lead to severe degeneration and the dying out of entire families. This hereditary burden is manifested as the absolute physical and mental inability to fight for survival (...). The endless line of deviants of all kind is well known: the eccentric, the lazy, the feeble-minded, the vagrant. Such individuals bear the seed of crime. We see that the tuberculosis-ridden and the socially defective marry freely. There should be a law that would limit the freedom of marriage and forbid marriage to drunks, infamous criminals, those ill with syphilis, the mentally ill. (...) Resources are wasted because of improper sentimentality on utterly hopeless charity, which immediately leads the healthy, strong, and intelligent to degeneration by preserving the week" (Kohout, 1911, 608-609). Bold sections by author. 
tuberculosis to "act as a manifold metaphor made it a malleable vehicle for social expression and discussion in the art and literature" (Byrne, 2013, 2). Croatian modernist literature translated the contradictions that characterized the medical understanding of tuberculosis at the turn of the $19^{\text {th }}$ century into a metaphor of social anxiety. The function of the metaphor was to indicate a deep discomfort that the spreading of TB, but also various mystifications of the disease encouraged by degeneration theory and eugenics, clearly provoked even in the Croatian society of that time. ${ }^{3}$

In Posljednji Stipančići (The Last Stipančići), "the best novel of Croatian realism," published in 1899, Lucija Stipančić, "the most layered and complex character in the entire Croatian literature of the $19^{\text {th }}$ century" $(\mathrm{Ne}-$ mec, 1994, 231), is portrayed as severely ill and, in the end, dying of tuberculosis. Although the central topic of the novel is, as its subtitle says, "the history of a patrician family" (Novak, 1964, 111) and its economic and moral decline, the portrayal of the fate of Lucija Stipančić, the daughter of Antun and Valpurga Stipančić, has drawn the attention of our literary historians the most. Lucija is "an innocent victim of her parents' lack of understanding, of outdated attitudes about obligation, and the merciless selfishness of a vile man of noble heritage" (Barac, 1964, 23-24), whereas "her intimate drama" is marked by a subtle psychological study of "repressed feelings of fear, neglect, and deception" (Nemec, 1994, 231).

Lucija is a symbol of both sacrifice and rebellion, and her moral purity increases as she continues to be exposed to humiliation and insults. She writes out her devastating "J'accuse" in the name of all humiliated and disenfranchised girls who have been deprived of the right to a life and joy. Her fate (...) reveals the backside of civil morality and patriarchal upbringing (Nemec, 1994, 232).

${ }^{3}$ The concept of illness as a metaphor is taken from several sources: directly from Sontag 1978, Byrne 2013 and Sparks 2015 and indirectly from Biti 2005. Since the paper is a part of a more extensive research and focuses on just one segment of the relationship between the ideas of abnormalities, Croatian civilian culture at the turn of the 19th century, and Croatian modern literature, the elaboration of the concept itself is not in the focus here. Therefore, its methodological and interpretative limitations are not discussed in the paper. In that sense, I would like to thank the reviewer for the valuable warnings that I intend to incorporate into the full version of the research. To the greatest extent, the paper is aligned with the thesis that "the way that (...) novels configure loosely medical topics into particular metaphors expresses the public impact of the condition or disease on a particular place and time - a mediation that fiction is uniquely able to represent" (Sparks, 2015, 140). 
Despite the open consensus concerning the narrative power and semantic significance of Lucija's character, literary historians completely ignore the fact that the narrative use of a medical topic and its reframing into a metaphor of illness actually serves to express fear in the community of that time. The fears of the quick and unstoppable spreading of an infection spill over to other public issues and become linked with various social and cultural events.

What blatantly stands out in Novak's fiction is the fact that Lucija's illness is never directly named. The described symptoms indicate, more or less clearly, that the girl suffers from pulmonary tuberculosis: fatigue, cough, chest pain, evening fever, coughing blood. But the novel, as it seems, aims to entice a feeling that "the very name of such a disease is felt to have a magic power" (Sontag, 1978, 6). Lucija's mother Valpurga is particularly adamant in her self-delusion. Even when she "notices a bloody edge of a quilt on the bed" (Novak, 1964, 273), she denies the infection and refuses to face its consequences. If the character of Valpurga can be interpreted as a representative of traditional values, whose behavior reflects prejudice and superstition, the character of the doctor is undoubtedly an agent of scientific knowledge. However, not even the doctor utters the diagnosis out loud during a house call, simply gesturing to the area "below her shoulders" (Novak, 1964, 276) as the source of the problem. Naming is almost identical to a death sentence. It is clear that in the Croatian society of the $19^{\text {th }}$ century, when modernization is moving forward at a faster pace and seems to be bringing nothing but progress, death becomes a taboo. According to progressivist and capitalist logic, death is "an offensively meaningless event, so that disease widely considered a synonym for death is experienced as something to hide" (Sontag, $1978,8)$. In other words, the refusal to directly name the disease in Novak's novel functions as a repression of the irrational. In a culture founded on rationalism and positivism - with the realistic novel as the desired appropriate expression - what cannot be scientifically explained literally causes fear. Therefore, the drive is to permanently place it into an ostensibly secure location (being deprived of a name) from which it often bursts out in the form of overwhelming feelings of collective panic and anxiety ${ }^{4}$. When tuberculosis

${ }^{4}$ According to Bauman, modernism strives to "deconstruct mortality" $(1992,10)$ by mapping the unsolvable and tabooed issued of death, "boasting scientific credentials" (Bauman, 
is portrayed through such intense linguistic denial in such a comprehensive narrative, which aims to be an accurate and detailed description of social reality, it is an evident symptom of cultural discomfort.

On the other hand, Posljednji Stipančići partly bears witness to the change in economic and class relations, to the rise of bourgeoisie and the working class, to the first accumulation of capital and the dying out of old technologies in shipping. Ante Stipančić owned several sailing boats, which at that time - in the 1830 s - began to give way to the technologically more advanced and, ultimately more cost-efficient, steamboats. ${ }^{5}$ Since the development of capitalism in the $19^{\text {th }}$ century was based on the optimism of high-level energy usability, the Stipančić family experienced economic ruin partly because they were unprepared for the industrialization and could not keep pace with the restructuring of trade relations. Lucija's illness, as a synecdoche of inherited family malaise and maladjustment, is in that sense a signal of "pathology of energy" (Sontag, 1978, 61). "Getting TB was thought to signify a defective vitality, or vitality misspent" (Sontag, 1978, 62). Lucija's infection, her restrained sexual and intellectual development, her passivation due to constantly being bound to the house - that "dungeon without light or air" (Novak, 1964, 124) - without contact with the outside word is undoubtedly at extreme odds with the capitalist idea of productivity. A lack of life energy and physical fatigue at a time of an energy boom provoked anxiety amongst the newly-minted bourgeoisie and the society at large, particularly one that strived for increased work efficiency and the utilization of capital. Lucija's nervous strain aroused by disturbed emotional existence, physical development inhibited by deceit, and existential and experiential poverty that stemmed from utter staticity, signal the bankruptcy of a family that failed to adapt to new economic tendencies. Tuberculosis is a metaphor of a life spent in vain and, speaking broadly, of a waste of capital and energy, completely misaligned with the $19^{\text {th }}$ century economic ideal.

The connection of tuberculosis with capitalism and vicious social stratification is more directly problematized by Leskovar's novella Katastrofa (Disaster) published in 1892. This somber portrayal of the final days of

1992, 152), as numerous and identifiable issues of health and illness that are, in principle, rationally "soluble".

${ }^{5}$ The first steam engine was mounted onto a ship built in the Kraljevica shipyard in 1836.

Cf. Bićanić, 1948. 
teacher Fran Ljubić, who is dying of TB, is actually a portrayal of social and class-related hardship. ${ }^{6}$ It is a complex congruence of illness and economic issues, where tuberculosis "possessed a symbolic potential as a metaphor for the consequences of capitalism" (Byrne, 2013, 5). Even though the narrative depicts the fate of a teacher from the Croatian countryside and does not directly refer to the potential malignancy of capitalist production, it is hard not to notice in it a harsh criticism of civil society, of the state apparatus, and the bureaucracy, as well as the need to strongly emphasize the existence of class differences. Naturally, Ljubić is not a factory worker; he is a proletarian in the truest sense of the word, a member of the lowest social class, who owns nothing except his body and the knowledge he sells as hired help for extremely low wages.

A paragraph at the end of the first chapter is particularly striking in that respect; we find out that a third of Ljubić's schoolmates died in a period of nine years due to utter poverty and oppression. If we consider the fact that education was a powerful signal of class and gender inequality, the demise of the teachers' caste indicates a discomfort related to the general issue of social inequality. The novella portrays tuberculosis as a metaphor of social corruption. Ljubić's work is the same as factory conveyor belt work.

Ah, yes, the early morning masses! Going to church every day from six to seven, getting up as early as five o'clock (...) Later at the school until noon, and then until nightfall, now that the days are short, and to think of repeat school, writing assignments, and (...) whatnot. The evenings he spends writing official reports... those are the office hours of an educator... (Leskovar, 1997, 42).

Despite this, his children are famished, and he needs to "go to the county office as often as ten times (...) to get that measly salary, and each time they hand him scant change, as if it were pittance" (Leskovar, 1997, 39). Ljubić is a disenfranchised, humiliated, economically ruined man whose illness is a direct consequence of toxic relations in the Croatian civil society of the late $19^{\text {th }}$ century. On the one hand, tuberculosis is depicted as a deadly infection that spreads from a society contaminated by injustice and economic order, whereas on the other hand, poverty and illness relate to an individual whose impeccable work ethics is at complete odds with his

${ }^{6}$ Cf. Milanja, 1987, 28. 
social and economic status. We are led to the conclusion that the novella emphasizes the fact that the budding Croatian civil society unscrupulously consumes the health of the proletariat for the needs of its own productivity and survival. At the end of his short life, Ljubic is portrayed as a drained, wasted body: "His arms have a deathly pallor, as if they were drained of blood and only empty, dark-blue, dead vessels remained" (Leskovar, 1997, 37). This body is nothing more than useless waste matter that is left after a working process. One part of the novella describes Ljubić's childhood from his point of view. Growing up in a country idyll, an oasis of "existential happiness" (Milanja, 1987, 29), is a reference to natural vitality and energy. Compared to this, it is obvious that hard work and a dreary life in poverty drained all of Ljubić's strength. In that sense, tuberculosis in this novella is a "metaphor for all that is wrong with the 'unnatural', capitalist world" (Byrne, 2013, 55).

The Croatian civil society of the late $19^{\text {th }} /$ early $20^{\text {th }}$ century was overcome by anxiety due to the possibility of irreparable damage to the health of the community, which is vital for its establishment. One of our first advocates of eugenics articulated the wide-spread belief that "the reproduction of less worthy, degenerated individuals" happens due to advancements in "medicine and hygiene" (Kohout, 1907, 103). Since death as an outcome of epidemics of hardly curable diseases mostly affected weaker individuals, the development of medicine led to their survival. This directly and adversely affected the development of future generations since inferior genetic material - instead of vanishing - survived, reproduced, and thus weakened the healthy part of the population.

We all know people with raised shoulders and narrow, sunken chest, who constantly combat "colds", and who pique our interest with their thick hair, gentle skin, vivacious, youthful spirit, and mental agitation, provoking pity with their obvious fragility. There you see the future degeneration of mankind. Such individuals now marry into healthy families and diminish the value of future generations. It will continue so unless there are other influences that will prevent the disease from spreading onto progeny. Haykraft claims that the prevention of infectious diseases weakens the human kind. The weak have perished, whereas others have gained immunity. The strongest of individuals have always been the only ones to survive (Kohout, 1907, 104).

According to Kohout, the total eradication of the causes of infectious diseases would significantly weaken the national community. Since it is 
not smart to prevent the development of medicine, he believes that "people who exhibit symptoms of hereditary diseases should be disallowed marriage and concubinage since it is a sin against one's own children and against human society" (Kohout, 1907, 133). Having in mind this and similar attitudes, which didn't stem only from the discourse of the then Croatian medicine, we can presume that Leskovar's Katastrofa points to petty bourgeoisie and, finally, capitalist obsession with health. The novella can thus be read as a representation of the deep pathology that lay in the core of that obsession: by imagining and using healthy bodies as the strongest fuel, civil society becomes a direct source of illness. Tuberculosis here functions as a catachresis of all deviations from civil society and its economic logic, but also of copious fears of the bourgeoisie.

Tuberculosis has another function in Croatian modernist literature. In the description of Lucija dying at the end of Posljednji Stipančici, one might notice that "tuberculosis (...) is associated with fragile loveliness and sexual attractiveness" (Byrne, 2013, 92).

Never has he seen such a human face. It was an artistic ideal of a young woman's head, crafted from the finest marble and imbued with lifelike qualities by the breath of the artist's soul. Dark hair cascaded from the white headboard, spreading lavishly across the silky cover, where Lucija's white, small hands lay dead. The shadow of eyes halfclosed and the crack in the small mouth was equally worth of thought as the moment when the spirit bid farewell to its lovely physical form (...) In this scene, in the most solemn quiet, it seemed to him as if the angelic dying virgin issued a silent command:

- Bow! (Novak, 1964, 294)

Admiration for the tuberculosis appearance arose in the age of romanticism. This type of female attraction was "an antithesis of traditional standards of beauty, which were associated with the appearance of good health" (Byrne, 2013, 93). It seems interesting that, in the typically realistic novel, Lucija was built as a romantic hero, a psychological vagabond immersed in her own oversensitivity and fantasized worlds. The very reason tuberculosis makes her physically constrained sets her spirit and sensitivity free. The metaphor of TB, according to Sontag, blends contrasts such as passion and passivity, sensuousness and angelic physiognomy, and sex appeal (Sontag, 1978, 25). It is exactly her illness that makes Lucija an embodiment of contradictions: spatial limitedness and unbound imagination; mental fragility and moral strength; chaste appearance and unfettered sexual desire. 
However, what sets her apart from other characters is her "superior sensitivity" (Sontag, 1978, 30), which makes her special, interesting, and mysterious. Lucija's tuberculosis is, therefore, a metaphor of utter individualism and a kind of spiritual escapism. Instead of pragmatically accepting the gender role that was imposed on her, Lucija identifies with a fictionalized role of an ideal mistress, which is a complete antithesis to the bourgeoisie idea of womanhood. Furthermore, since father Ante wrongly invested all of the funds and the family fortune into the education of his son Juraj, Lucija's illness is a symptom of that investment disaster. In this novel, TB is a signal of resistance to the capitalist and petty bourgeoisie gender politics. From her father's perspective, Lucija is abnormal, degendered, incapable of realizing her potential within the patriarchal family norms. In that sense, Lucija's illness is a symbolic reservoir in which the $19^{\text {th }}$ century culture stored abnormalities it was not ready to face.

The fate of Arsen Toplak, the hero of Kamov's novel Isušena kaljuža (The Dried-up Mire), written between 1906 and 1909, bears witness to the fact that the metaphor of tuberculosis in the Croatian modernist literature covered various forms of apostasy. In the initial narration, we find out that Arsen has lung abscess. He coughs blood and finds out he is infected. Quickly after facing the fact that he has a "bacillus within" (Kamov, 1997, 18), the hero reaches the conclusion that it is a disease "that alienates man, removes him from society, and reduces him to himself" (Kamov, 1997, 18). Isušena kaljuža confirms the idea of tuberculosis as "a disease of the soul" (Sontag, 1978, 18), a cultural metaphor that affirms "the value of being more conscious, more complex psychologically. Health becomes banal, even vulgar" (Sontag, 1978, 26). According to Sontag, in the early $19^{\text {th }}$ century, TB was linked to creativity, bohemian life, and creative leisure that rejected the obligations imposed by the bourgeoisie dogma of work and earned living. The patient was "a wanderer in endless search of the healthy place" (Sontag, 1978, 33). Arsen is portrayed exactly in that manner. His travels to the south are in line with the beliefs of $19^{\text {th }}$ century medicine that a warmer climate helped improve well-being. Afterwards, he becomes an apostate and a writer who sees writing "as a sublimation of his illness" (Biti, 2005, 31). In his complex and comprehensive reading, Biti warns that the illness metaphor has deconstructive potential since it points to the problematic nature of assuming identity positions and related 
areas of authority. Tuberculosis infects the subjects, so it's a question of "a paradoxical relation of oneself in the other as the other in oneself. This means that every identity is flawed from the beginning" (Biti, 2005, 36).

In that respect, it is indicative that here TB is not portrayed as a consequence of the toxic society, but as a "disease that individualizes, that sets a person in relief against the environment" (Sontag, 1978, 37), "a disease that isolates one from the community" (Sontag, 1978, 38). The novel literally claims that Arsen "is no longer available to society" (Kamov, 1997, 18). However, being infected with tuberculosis both defines and destroys his masculine identity. On the one hand, Arsen's manhood is weakened by the disease. He is obsessed with constant doubts about his own virility, perverse drives, and incestuous desires. Confounded by the torpidity of his libido, Arsen asks himself "is it impotence" (Kamov, 1997, 21) and immediately makes a connection with tuberculosis, with the issue of gender, and the obscene physical admiration for his sister. It is clear that the illness metaphor blended several different abnormalities that threatened the stability of the then Croatian bourgeoisie. Tuberculosis signals the behaviors and conditions that seek the activation of eugenic mechanisms. At the turn of the $19^{\text {th }}$ century, it was believed that "medicine, education, and social hygiene were seen as the means to prevent debauchery and create a socially acceptable sexual standard" (Oosterhuis, 2000, 28). A strictly regulated sexuality of the bourgeoisie was a powerful normalization mechanism that was basically sparked by the idea of preserving the vitality and strength of the new national community. Arsen's disease is thus clear proof of anxiety induced by perverted sexuality that arises in the Croatian civil society of that time under the pressure of population politics. If we consider the fact that the mechanism of sexuality does not exist solely for the purpose of reproduction, but for the multiplication, engagement, unification, and a detailed penetration into bodies and total control of the population (Foucault, 1982, 95), then Arsen's abnormal sexual drive, as the consequence of TB, is diametrically opposed to the needs of the capitalist economy for health, for strong, and correctly controlled individuals.

But the illness marks Arsen in a different manner as well. It makes him an intellectually superior and entirely focused interpreter of his own mental states and complex social processes. "Thoughts and words did not bear such wealth before. (...) The weaker, the stronger" (Kamov, 1997, 28). 
The illness finally enables him to set himself free from the normal, petty bourgeoisie worldview and opens the pathway to destructive self-analysis. At the end of the novel, on his third trip, in a voluntary exile of sorts, Arsen's identity is established through total decomposition: "I am not me" (Kamov, 1997, 353). At that point, the tuberculosis, as the explosive source of the autoanalytical process, paradoxically conjoins the construction and destruction of the civil subject, marking the zone of indecisiveness in the area of identity, which the burgeoning Croatian bourgeoisie society aims to normalize at any cost. Tuberculosis is thus a metaphor of insecurity that appears on the border of masculinity and femininity, of normalcy and perversion, of the national and the foreign, of the capitalist and the proletarian class in bourgeoisie society. In that respect, it brings to light various risky gender, legal, medicine, population, and economic issues that arise at the time the Croatian civil society and the Croatian nation are beginning to form. Here is a longer paragraph of Arsen's narration that clearly echoes some of these issues:

I developed an illness of lungs. It happened last year. The illness faced me towards myself and I began to study myself. And I discovered not only the ailment of the lungs, but also of the thoughts, feelings, sex (...) A bacillus in the lungs, an upheaval of the thoughts, an absurdity of feelings, a perversity of sex. I individualized myself: I separated from the society (...) And I said: Isn't individuality a definition of the diseased? Isn't an illness the prerequisite of individuality? And isn't reproduction the denying of individuality? If so, asceticism is individuality. But if individuality is debauchery, satisfaction, pleasure - then individuality cannot be ascetic. Sexuality must then be set free, but children are not to be made. One must - be perverse! (Kamov, 1997, 141).

The medicinal term of tuberculosis here clearly represents the fears that arose in the Croatian bourgeoisie culture due to the weakening of gender borders, the increase in instances of risky sexual behavior, and the potential depopulation, which are the basic impediments to the fulfilment of the idea of capitalist productivity, progress, and national self-formation. Finally, TB is used as a form of criticism of the advocates of degeneration theory and eugenics in the territories of Croatia, who at the time tried to address complex social issues such as the relation to the abnormal, the misfit, the weird, or the monstrous other in general. With its aestheticization and rhetoricization of tuberculosis, Kamov's novel Isušena kaljuža and the other texts analyzed in this article become an essential background 
for the evaluation and problematization of the modernization processes of the Croatian civil society that are not politically or ethically neutral in the least. But they are also a starting ground for facing our own prejudices and fears that arise from contact with ostensibly hideous, diseased, and perverse instances of contemporary Croatian culture.

\section{References}

Barac, A. (1964). Vjenceslav Novak [foreword]. In: Vjenceslav Novak. Ed. V. Barac. Zagreb: Matica hrvatska, pp. 7-26.

Bauman, Z. (1992). Mortality, Imortality and Other Life Strategies. Stanford: Stanford University Press.

Biti, V. (2005). Uzgoj eksplozije. 'Logika apsurda' in "Isušenoj kaljuži” Janka Polića Kamova. In: Doba svjedočenja. Zagreb: Matica hrvatska, pp. 31-51.

Bićanić, R. (1948). Industrijska revolucija u Hrvatskoj i godina 1848. "Historijski zbornik", 1 (1), pp. 67-102.

Byrne, K. (2013). Tuberculosis and the Victorian literary Imagination. Cambridge-New York: Cambridge University Press.

Dežman, M. (1904). Aetiologija, prophylaksa i therapija tuberkuloze prema današnjem stanju znanosti. „Liečnički viestnik”, 9 (26), pp. 284-289; 10(26), pp. 316-322; 11 (26), pp. 357-364; 12 (26), pp. 410-423.

Foucault, M. (1982). Istorija seksualnosti. Volja za znanjem. Belgrade: Prosveta.

Greeenslade, W. (2010). Degeneration, Culture and the Novel. Cambridge-New York: Cambridge University Press.

Hoholač, J. (1899). Sredstva proti širenju tuberkuloze nastale užitkom mesa i mlieka od tuberkuloznih krava. "Liečnički viestnik", 6 (21), pp. 188-192.

Kamov, J.P. (1997). Isušena kaljuža. Zagreb: Konzor.

Kohout, B. (1907). Degeneracija čovječeg pokoljenja. "Liečnički viestnik", 4 (29), pp. 98-104; 5 (29), pp. 133-139.

Kohout, B. (1911). Higijena društva (Eugenia). "Liečnički viestnik”, 11 (33), pp. 546-553; 12 (33), pp. 604-610.

Leskovar, J. (1997). Katastrofa. Ed. C. Milanja. Zagreb: Matica hrvatska, pp. 37-50.

Milanja, C. (1987). Janko Leskovar. Zagreb: Zavod za znanost o književnosti.

Nemec, K. (1994). Povijest hrvatskog romana od početaka do kraja 19. stoljeća. Zagreb: Nakladni zavod Znanje.

Novak, V. (1964). Posljednji Stipančići. Ed. V. Barac. Zagreb: Matica hrvatska, pp. 111-296.

Oosterhuis, H. (2000). Stepchildren of nature. Krafft-Ebing, Psychiatry, and the Making of Sexual Identity. Chicago-London: The University of Chicago Press.

Sontag, S. (1978). Illness as Metaphor. New York: Farrar, Straus and Giroux. 
Sparks, T. (2015). Illness as Metaphor in the Victorian Novel: Reading Popular Fiction Against Medical History. In: Victorian Medicine and Popular Culture. Eds L. Penner, T. Spark. London: Pickering \& Chatto, pp. 137-146.

Vuković, T. (2016). Grdoba napretka. Degeneracija, kultura normalizacije i hrvatska književnost na prijelazu iz 19. u 20. stoljeće. „Romanoslavica”, 2 (52), pp. 437-450. 